\title{
Silanes and Siloxanes Thermal Conductivity in the Liquid Phase: A Critical Review and an Improved Prediction Method
}

\author{
Giovanni Latini*, Giorgio Passerini \\ Università Politecnica delle Marche, Via Brecce Bianche, Ancona 60131, Italy \\ Corresponding Author Email: giovanni.latini@univpm.it
}

https://doi.org/10.18280/ti-ijes.652-411

Received: 2 April 2021

Accepted: 30 May 2021

\section{Keywords:}

liquids, thermal conductivity, silanes, siloxanes

\begin{abstract}
The thermal conductivity $\lambda$ of the silanes and siloxanes families in the liquid phase at atmospheric pressure or along the saturation line is investigated as function of the reduced temperature. Because of the large scarcity or even of the lack of accurate experimental $\lambda$ data an empirical equation is proposed as a generalization based on investigations presented in previous works $[1,2]$. The families of silanes and siloxanes (21 chlorosilanes, 5 cyclosiloxanes, 10 linear siloxanes, 10 silanes and 19 other silanes) are taken into consideration using a large database [3] in order to extend the use of a general formula valid for organic compounds (alcohols, alkanes, ketones,....) and to improve preceeding results obtained in the case of the cited silanes and siloxanes, for which experimental thermal conductivity data at atmospheric pressure or along the saturation line in the liquid phase are available in very few cases. The equation is proposed as acceptable for engineering purposes and comparable with the existing prediction methods [3]. The database DIPPR [3] in the version 2020 containing a linear correlation with various parameters is taken into account, also considering the results of 7 other prediction methods existing in the technical and scientific literature. An extensive and critical comparison points out that the method proposed in this work can be considered valid with absolute errors usually not greater than $5 \%$.
\end{abstract}

\section{INTRODUCTION}

As well known the Fourier's law [4], for example in the mono-dimensional case, contains the thermal conductivity $\lambda$ :

$$
\mathrm{dq}=-\lambda \mathrm{dA} \frac{\mathrm{dT}}{\mathrm{dx}}
$$

where, dq is the heat flow along the $\mathrm{x}$ axis, $\mathrm{dA}$ is an infinitesimal area normal to the direction $\mathrm{x}$ and $\mathrm{T}$ is the temperature. The SI units are used, unless differently stated.

The thermal conductivity $\boldsymbol{\lambda}$ of the substances in the liquid phase is closely related to temperature, pressure and chemical structure, but rigorous theoretical investigations, based on classical or quantum mechanics, lead to general results usually not acceptable for engineering purposes because of large errors; the theory of the liquid state is far away from producing acceptable results when, for example, the saturation line is investigated. In the liquid phase reasonable approximations are available only for some compounds characterized by simple chemical structure and in any case when several ad hoc constants are introduced. For gases and solids on the contrary models based on the similitaries with the characteristics of the perfect gas and on the crystalline simmetries respectively are valid instruments for general theories. Moreover, accurate experimental thermal conductivity data for compounds in the liquid state are very often not available at all, and due to the lack of a general theory, empirical or semiempirical equations can provide reasonably accurate thermal conductivity data valid for engineering purposes. In this work, on the basis of investigations presented in previous papers $[1,2]$ the families of silanes and siloxanes ( 21 chlorosilanes, 5 cyclosiloxanes, 10 linear siloxanes, 11 silanes and 20 other silanes) are taken into consideration using a larger database [3] in order to extend the use of a general formula valid for organic compounds (alcohols, alkanes, ketones,....) and to improve preceeding results obtained in the case of the cited silanes and siloxanes, for which experimental thermal conductivity data at atmospheric pressure or along the saturation line in the liquid phase are available in very few cases. Substantially two parameters characterize the thermal conductivity of the investigated compounds, the first is an exponent a, the same for the all the compounds of the family, and the second is $\lambda 0.618$, that is the thermal conductity estimated at the value of the reduced temperature equal to $(\Phi-1)$ the mantissa of the "golden ratio" $\Phi=(1+\sqrt{5}) / 2=1.618033 \ldots$ The proposed method is acceptable for engineering purposes and comparable with the method proposed by DIPPR [3] (a linear correlation with various and different parameters). An extensive and critical comparison between very different methods points out that the method proposed in this work can be considered valid with absolute errors not greater than 5\%.

Because the dependence of the thermal conductivity $\lambda$ upon the pressure $\mathrm{P}$ for the compounds in the liquid phase is negligible up to $40-50$ bar, only the temperature is taken into account in this work concerning $\lambda$ at atmospheric pressure or along the saturation line. On the other hand, as above pointedout, very few accurate experimental $\lambda$ values for liquids as function of temperature are available in technical and scientific literature. Moreover, with very limited exceptions, 
from the normal melting point to the normal boiling point and over, the liquid thermal conductivity decreases almost linearly, and the critical point represents a singularity.

Some interesting models [5] present the liquid thermal conductivity as function of temperature and density by the sum of three contributions ("dilute gas contribution", "excess contribution" and "critical enhancement contribution"), but in this work, because the explored range is near or along the saturation line, the density dependence, as for the pressure dependence, is neglected.

\section{THE PREVIOUS EQUATIONS}

The large review contained in $[1,2]$ presents a summary of the empirical or semi-empirical methods appeared in the literature and presented as suggested by Govender [6]: general correlation methods, family methods, group contribution methods and corresponding state methods. The collection due to Horvath [7] and the classical book of Poling, Prausnitz and O'Connell [8] were also taken into account.

The work of Latini and his group [9-11] began in the 80's with the equation, reported also by Poling, Prausnitz and O'Connel [8]:

$$
\lambda=\mathrm{A} \frac{\left(1-\mathrm{T}_{\mathrm{r}}\right)^{0.38}}{\mathrm{~T}_{\mathrm{r}}^{\frac{1}{6}}}
$$

$T_{r}=\mathrm{T} / \mathrm{T}_{\mathrm{c}}$ is the reduced temperature, the factor $\boldsymbol{A}$ depends upon molecular weight $\mathbf{M}$, critical temperature $\mathbf{T}_{\mathbf{c}}$, normal freezing point $\mathbf{T}_{\mathbf{f}}$ and normal boiling point $\mathbf{T}_{\mathbf{b}}$.

A deepest exploration of the experimental $\lambda$ data and a suitable mathematical apparatus $[1,2]$ lead to the expression:

$$
\lambda=A\left[\sqrt{5} \frac{\left(\Phi-T_{r}\right)^{2}}{\left(\Phi+T_{r}\right)}\right]^{a}
$$

$\Phi$ is the "golden ratio", the limit of the Fibonacci's sequence:

$$
\Phi=\lim _{n \rightarrow \infty} \frac{F_{n-1}}{F_{n}}=\frac{1+\sqrt{5}}{2}=1.618033989 \ldots
$$

Otherwise given by: $\Phi=1+1 / \Phi$. $\Phi$ can be considered as characteristic of the liquid phase, the exponent a of the investigated family and $\mathbf{A}$ (which has the units Watt $/(\mathrm{m} \cdot \mathrm{K})$ of $\lambda$ ) is characteristic of the single compound and is equal to the value of the thermal conductivity when $\operatorname{Tr}=0.618033989 \ldots$, the mantissa of the "golden ratio", usually a value near the reduced normal boiling point.

The first attempt for an expression for A was as follows for the organic family of alcohols [1] and also for alkanes, ketones and silanes [2] :

$$
\mathrm{A}=\mathrm{h} \frac{\mathrm{T}_{\mathrm{c}}^{\frac{5}{4}}}{\mathrm{M}^{\frac{1}{2}}}
$$

where, $\mathrm{h}$ is a value characteristic of the single family.

\section{THE PROPOSED EQUATION}

In this work the Eq. (3) is examined again with respect to A which is given by expression (5); this procedure changes the problem from A to $\mathrm{h}$ and, while A has a precise meaning (it is the thermal conductivity at the reduced temperature $\mathrm{Tr}=0.618 \ldots$. , h derives from a process of optimization and has units of measure without any particular meaning. Substantially the factor $\mathrm{h}$ and the exponent a are coupled to give the minimum mean absolute deviation between experimental (when available) and predicted $\lambda$ data. Finally, at the end of the mathematical examination, the value of the factor $h$ determines the value of the exponent a and vice versa; moreover, the exponent a is adimensional and is linked to the slope of the function (3) at every value of the reduced temperature. What is proposed is to return to the physical meaning of $\mathrm{A}$, that is:

$$
A=\lambda 0.618033989 \ldots
$$

At this point the value of $\mathrm{A}$ has to be found in the scientific and technical literature, rendering the choice of the exponent a entirely independent. In any case the liquid thermal conductivity, which is quite linear as function of the temperature, depends upon two parameters and what is proposed is to accept expression (6) in order to search for the value of $\mathbf{a}$. The procedure adopted in this work is based on the following points:

- $\quad$ the value of (6) is taken from the Database DIPPR (3);

- the families taken into account are Silanes and Siloxanes.

The choice of the Database DIPPR has the following reason:

- the available liquid experimental or predicted $\lambda$ data in technical and scientific literature are by different apparatuses and mathematical procedures with very different accuracies;

- the test of Eq. (5) where A is given by expression (6) has to be developed by taking into account the large, updated and reliable collection of thermal conductivity data contained in the DIPPR database: the $\lambda$ data are clearly reported as experimental, predicted and smoothed; in any case the accuracy of the thermal conductivity data is clearly indicated.

\section{THE TEST OF EQUATION (5) WHEN A IS GIVEN BY EXPRESSION (6)}

Silanes and siloxanes are silicon derived compounds and the monomers that form the semi-inorganic polymers based on silicon derive from nomenclature of silane $\mathrm{SiH}_{4}$ in analogy to the organic polymers whose terminology is compared to the methane. The fluids can be grouped in four different subgroups: chlorosilanes (21 compounds), cyclosiloxanes (5 compound), linear siloxanes (10 compounds), silanes (10 compounds) and "other" silanes (19 Compounds).

The explored reduced temperature range was usually from 0.30 to 0.80 (practically from the normal melting point to the normal boiling point) at atmospheric pressure or along the saturation line.

Tables 1-5 contain for the compounds of each family: name of the compound, structure of the compound, molecular weight $\mathrm{M}$, critical temperature $\mathrm{T}_{\mathrm{c}}$, reduced temperature ranges of the investigation, the claimed error by DIPPR, value of a, value of $\lambda 0.618$ and the general results (average absolute deviations $\Delta_{\mathrm{m}} \%$ and maximum absolute deviations $\Delta_{\mathrm{M}} \%$ between the thermal conductivity values calculated by Eqns. (5) and (6) and the corresponding experimental or experimental \& predicted values by DIPPR. 
Table 1. Chlorosilanes

\begin{tabular}{|c|c|c|c|c|c|c|c|}
\hline COMPOUND & Structure & $M[\mathbf{k g} / \mathbf{k m o}]$ & $\Delta \mathrm{Tr}$ & $\begin{array}{c}\lambda(\mathrm{DIPPR} \\
\text { claimed error) }\end{array}$ & $\lambda 0.618$ & $\Delta \mathbf{m} \%$ & $\mathbf{M \%}$ \\
\hline $\begin{array}{l}\text { MONOCHLORO } \\
\text { SILANE }\end{array}$ & $\mathrm{H} 3 \mathrm{SiCl}$ & 66.56230 & $399.200 .39-0.61$ & $<10 \%$ & 0.500 .162584 & 40.2 & 0.5 \\
\hline METHYL CHLOROSILANE & $\mathrm{CH} 3 \mathrm{SiH} 2 \mathrm{Cl}$ & 80.58890 & $442.000 .31-0.64$ & $<25 \%$ & 0.500 .140696 & 50.8 & 2.3 \\
\hline DIMETHYLCHLOROSILANE & $(\mathrm{CH} 3) 2 \mathrm{SiHCl}$ & 94.61548 & $472.000 .34-0.65$ & $<25 \%$ & 0.500 .117486 & 50.4 & 1.4 \\
\hline $\begin{array}{l}\text { DICHLORO } \\
\text { SILANE }\end{array}$ & $\mathrm{H} 2 \mathrm{SiCl} 2$ & 101.00738 & $451.500 .33-0.80$ & $<10 \%$ & 0.500 .167208 & 1.6 & 4.9 \\
\hline $\begin{array}{l}\text { TRIMETHYL } \\
\text { CHLOROSILANE }\end{array}$ & (CH3)3SiCl & 108.64206 & $497.750 .43-0.66$ & $<25 \%$ & 0.500 .124639 & 0.2 & 0.4 \\
\hline METHYL DICHLOROSILANE & $\mathrm{CH} 3 \mathrm{SiHCl} 2$ & 115.03396 & $483.000 .38-0.65$ & $<25 \%$ & 0.500 .123587 & 70.2 & 0.8 \\
\hline $\begin{array}{c}\text { DIMETHYL } \\
\text { DICHLOROSILANE }\end{array}$ & $(\mathrm{CH} 3) 2 \mathrm{SiCl} 2$ & 129.06054 & $520.350 .38-0.66$ & $<25 \%$ & 0.500 .124665 & 50.2 & 0.9 \\
\hline $\begin{array}{l}\text { TRICHLORO } \\
\text { SILANE }\end{array}$ & $\mathrm{SiHCl} 3$ & 135.45244 & $479.000 .30-0.79$ & $<10 \%$ & 0.500 .117347 & 70.7 & 3.1 \\
\hline METHYL VINYL DICHLOROSILAI & $\mathrm{CH} 2 \mathrm{CHSiCH} 3 \mathrm{Cl} 2$ & 141.07124 & $544.100 .33-0.67$ & $<25 \%$ & 0.500 .09 & 30.4 & 1.5 \\
\hline METHYL TRICHLOROSILANE & $\mathrm{CH} 3 \mathrm{SiCl} 3$ & 149.47902 & $517.000 .38-0.66$ & $<10 \%$ & 0.500 .137143 & 0.2 & 0.9 \\
\hline $\begin{array}{l}\text { DICHLORODIETHYL } \\
\text { SILANE }\end{array}$ & $\begin{array}{l}(\mathrm{CH} 3 \mathrm{CH} 2) \mathrm{SiCl} 2 \\
(\mathrm{CH} 2 \mathrm{HC} 3)\end{array}$ & 157.11370 & $595.750 .30-0.80$ & $<10 \%$ & 0.500 .117754 & 40.8 & 3.4 \\
\hline $\begin{array}{l}\text { VINYLTRICHLORO } \\
\text { SILANE }\end{array}$ & $\mathrm{CH}$ & 161.489 & $543.150 .33-0.80$ & $<10 \%$ & 0.500 .120556 & 50.8 & 3.3 \\
\hline $\begin{array}{l}\text { ETHYLTRICHLORO } \\
\text { SILANE }\end{array}$ & $\mathrm{CH} 3 \mathrm{CH} 2 \mathrm{SiCl} 3$ & 163.50600 & $559.950 .30-0.66$ & $<25 \%$ & 0.500 .118027 & 70.8 & 2.8 \\
\hline $\begin{array}{l}\text { TETRACHLORO } \\
\text { SILANE }\end{array}$ & $\mathrm{SiCl} 4$ & 169.89750 & $507.000 .56-0.65$ & $<25 \%$ & 0.500 .097490 & 1.5 & 3.4 \\
\hline $\begin{array}{c}\text { 3-CHLOROPROPYL } \\
\text { DIMETHYLCHLOROSILANE }\end{array}$ & $\begin{array}{l}\mathrm{ClCH} 2 \mathrm{CH} 2 \mathrm{CH} 2 \mathrm{Si} \\
(\mathrm{CH} 3) 2(\mathrm{Cl})\end{array}$ & i 171.14000 & $640.700 .30-0.80$ & $<10 \%$ & 0.50 .109399 & 0.8 & 3.4 \\
\hline $\begin{array}{l}\text { PHENYLMETHYL } \\
\text { DICHLOROSILANE }\end{array}$ & $\left(\mathrm{C}_{6} \mathrm{H} 5\right) \mathrm{Si}(\mathrm{CH} 3) \mathrm{Cl} 2$ & 2191.12992 & $689.000 .33-0.69$ & $<25 \%$ & 0.500 .096997 & $7 \quad 0.3$ & 1.1 \\
\hline PHENYLTRICHLOROSILANE & (C6H5)SiCl3 & 211.54840 & 688.000.34-0.69 & $<10 \%$ & 0.500 .102081 & 0.3 & 1.0 \\
\hline $\begin{array}{l}\text { 3-CHLOROPROPYL } \\
\text { TRICHLOROSILANE }\end{array}$ & $\mathrm{SiCl} 3(\mathrm{CH} 2) 3 \mathrm{Cl}$ & 211.97700 & $661.100 .34-0.69$ & $<10 \%$ & 0.500 .114226 & 60.3 & 0.7 \\
\hline $\begin{array}{c}\text { DIPHENYL } \\
\text { DICHLOROSILANE }\end{array}$ & (C6H5)2SiCl2 & 253.19930 & $814.000 .31-0.71$ & $<10 \%$ & 0.500 .086738 & 0.8 & 2.4 \\
\hline $\begin{array}{l}\text { (3-METHYLACRYLOXYPROPYL) } \\
\text { TRICHLOROSILANE }\end{array}$ & $\begin{array}{c}\mathrm{CH} 2=\mathrm{C}(\mathrm{CH} 3) \mathrm{COO} \\
(\mathrm{CH} 2) 3 \mathrm{SiCl} 3\end{array}$ & 261.60600 & $708.100 .31-0.74$ & $<25 \%$ & 0.500 .088924 & 41.0 & 3.4 \\
\hline $\begin{array}{l}\text { HEXACHLORO } \\
\text { SILANE }\end{array}$ & $\begin{array}{c}\mathrm{CH} 2=\mathrm{C}(\mathrm{CH} 3) \mathrm{COO} \\
(\mathrm{CH} 2) 3 \mathrm{SiCl} 3\end{array}$ & 268.889 & $599.70 .45-0.70$ & $<25 \%$ & 0.500 .083807 & $7 \quad 0.8$ & 2.3 \\
\hline
\end{tabular}

Table 2. Cyclosiloxanes

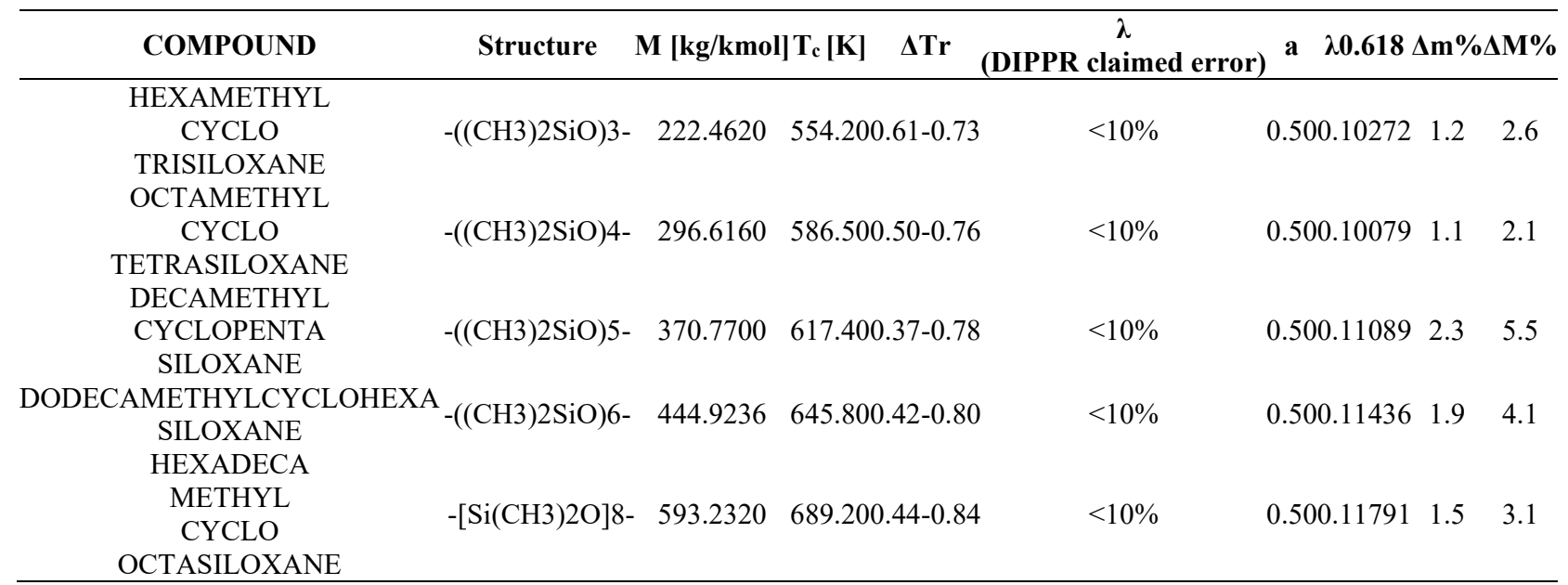

Table 3. Linear siloxanes

\begin{tabular}{|c|c|c|c|c|c|c|c|c|c|}
\hline COMPOUND & Structure & M [kg/kmol] & ] $\mathbf{T}_{\mathrm{c}}[\mathrm{K}]$ & $\Delta \mathrm{Tr}$ & (DIPPR & $\begin{array}{l}\lambda \\
\text { claimed error) }\end{array}$ & a $\lambda 0.618$ & $\Delta \mathrm{m} \%$ & $\Delta \mathrm{M} \%$ \\
\hline $\begin{array}{l}\text { HEXAMETHYL } \\
\text { DISILOXANE }\end{array}$ & $(\mathrm{CH} 3) 3 \mathrm{SiOSi}(\mathrm{CH} 3) 3$ & 3775 & 519.0 & 90 & & $<10 \%$ & 0.350 .09904 & 2.2 & 4.2 \\
\hline $\begin{array}{l}\text { OCTAMETHYL } \\
\text { TRISILOXANE }\end{array}$ & $\begin{array}{c}(\mathrm{CH} 3) 3 \mathrm{SiOSi}(\mathrm{CH} 3) 2 \\
\mathrm{OSi}(\mathrm{CH} 3) 3\end{array}$ & 236.53100 & 564.4 & $.34-0.90$ & & $<10 \%$ & 0.350 .09824 & 1.4 & 3.0 \\
\hline HEXACHLORO & $\mathrm{Cl}[\mathrm{Si}](\mathrm{Cl})(\mathrm{Cl}) \mathrm{O}[\mathrm{Si}]$ & 284.89000 & 594.70 & $.41-0.55$ & & $<10 \%$ & 0.350 .08139 & 3.3 & 6.9 \\
\hline
\end{tabular}




\begin{tabular}{|c|c|c|c|c|c|c|c|}
\hline DISILOXANE & $(\mathrm{Cl})(\mathrm{Cl}) \mathrm{Cl}$ & & & & & & \\
\hline $\begin{array}{l}\text { DECAMETHYL } \\
\text { TETRASILOXANE }\end{array}$ & $\begin{array}{c}(\mathrm{CH} 3) 3 \mathrm{SiO}(\mathrm{Si}(\mathrm{CH} 3) 2 \mathrm{O}) 2 \\
\mathrm{Si}(\mathrm{CH} 3) 3\end{array}$ & 310.68500 & $599.400 .34-0.90$ & $<5 \%$ & 0.350 .09800 & 0.4 & 1.1 \\
\hline $\begin{array}{l}\text { DODECAMETHYL } \\
\text { PENTASILOXANE }\end{array}$ & $\begin{array}{c}(\mathrm{CH} 3) 3 \mathrm{SiO}(\mathrm{Si}(\mathrm{CH} 3) 2 \mathrm{O}) 3 \\
\mathrm{Si}(\mathrm{CH} 3) 3\end{array}$ & 384.83900 & $628.400 .31-0.80$ & $<10 \%$ & 0.350 .10228 & 0.1 & 0.5 \\
\hline $\begin{array}{c}\text { TETRADECA } \\
\text { METHYL } \\
\text { HEXASILOXANE }\end{array}$ & $\begin{array}{c}(\mathrm{CH} 3) 3 \mathrm{SiO}(\mathrm{Si}(\mathrm{CH} 3) 2 \mathrm{O}) 4 \\
\mathrm{Si}(\mathrm{CH} 3) 3\end{array}$ & 458.99300 & $653.200 .33-0.88$ & $<10 \%$ & 0.350 .10662 & 0.4 & 1.0 \\
\hline $\begin{array}{c}\text { HEXADECA } \\
\text { METHYL } \\
\text { HEPTASILOXANE }\end{array}$ & $\begin{array}{c}(\mathrm{CH} 3) 3 \mathrm{SiO}(\mathrm{Si}(\mathrm{CH} 3) 2 \mathrm{O}) 5 \\
\mathrm{Si}(\mathrm{CH} 3) 3\end{array}$ & 533.14700 & $671.800 .29-0.83$ & $<10 \%$ & 0.350 .11192 & 0.1 & 0.5 \\
\hline $\begin{array}{c}\text { OCTADECA } \\
\text { METHYL } \\
\text { OCTASILOXANE }\end{array}$ & $\begin{array}{c}(\mathrm{CH} 3) 3 \mathrm{SiO}(\mathrm{Si}(\mathrm{CH} 3) 2 \mathrm{O}) 6 \\
\mathrm{Si}(\mathrm{CH} 3) 3\end{array}$ & 607.30100 & $688.900 .31-0.85$ & $<25 \%$ & 0.350 .11725 & 0.2 & 0.7 \\
\hline $\begin{array}{l}\text { EICOSAMETHYL } \\
\text { NONASILOXANE }\end{array}$ & $\begin{array}{c}\mathrm{Si}(\mathrm{CH} 3) 3 \mathrm{O}(\mathrm{Si}(\mathrm{CH} 3) 2 \mathrm{O}) 7 \\
\mathrm{Si}(\mathrm{CH} 3) 3\end{array}$ & 681.45500 & $707.200 .29-0.86$ & $<25 \%$ & 0.350 .12247 & 0.4 & 1.2 \\
\hline $\begin{array}{c}\text { HEXACOSA } \\
\text { METHYL } \\
\text { DODECASILOXANE }\end{array}$ & $\begin{array}{c}\mathrm{Si}(\mathrm{CH} 3) 3 \mathrm{O}(\mathrm{Si}(\mathrm{CH} 3) 2 \mathrm{O}) 10 \\
\mathrm{Si}(\mathrm{CH} 3) 3\end{array}$ & 903.91700 & $751.300 .27-0.89$ & $<25 \%$ & 0.350 .13910 & 1.1 & 2.7 \\
\hline
\end{tabular}

Table 4. Silanes

\begin{tabular}{|c|c|c|c|c|c|c|c|c|}
\hline COMPOUND & Structure & $\begin{array}{c}\mathbf{M} \\
{[\mathrm{kg} / \mathrm{kmol}]}\end{array}$ & $\mathbf{T}_{\mathbf{c}}[\mathbf{K}]$ & $\begin{array}{l}\lambda \text { (DIPPR claimed } \\
\text { error) }\end{array}$ & $\mathbf{a}$ & $\lambda 0.618$ & $\Delta \mathrm{m} \% \Delta$ & $\Delta \mathrm{M} \%$ \\
\hline SILANE & $\mathrm{SiH} 4$ & 32.11726 & $269.700 .33-0.60$ & $<25 \%$ & 0.80 & 0.1120 & 1.8 & 2.5 \\
\hline METHYL SILANE & $\mathrm{CH} 3 \mathrm{SiH} 3$ & 46.14384 & $352.500 .33-0.61$ & $<25 \%$ & 0.50 & 0.1584 & 0.8 & 2.2 \\
\hline DIMETHYL SILANE & $(\mathrm{CH} 3) 2 \mathrm{SiH} 2$ & 60.17042 & $402.000 .31-0.63$ & $<25 \%$ & 0.50 & 0.1458 & 0.9 & 2.6 \\
\hline TRIMETHYL SILANE & $(\mathrm{CH} 3) 3 \mathrm{SiH}$ & 74.19700 & $432.000 .32-0.65$ & $<25 \%$ & 0.50 & 0.1215 & 0.7 & 2.1 \\
\hline $\begin{array}{l}\text { TETRAMETHYL } \\
\text { SILANE }\end{array}$ & $\mathrm{Si}(\mathrm{CH} 3) 4$ & 88.22358 & $450.400 .39-0.67$ & $<25 \%$ & 0.50 & 0.1215 & 0.2 & 0.7 \\
\hline TRISILANE & $\begin{array}{c}{[\mathrm{SiH} 3][\mathrm{SiH} 2]} \\
{[\mathrm{SiH} 3]}\end{array}$ & 92.32000 & $495.900 .31-0.80$ & $<10 \%$ & 0.50 & 0.1384 & 0.7 & 3.3 \\
\hline n-TETRASILANE & $\begin{array}{c}\mathrm{SiH} 3 \mathrm{SiH} 2 \mathrm{SiH} 2 \\
\mathrm{SiH} 3\end{array}$ & 122.421 & $570.600 .31-0.80$ & $<10 \%$ & 0.5 & 0.1417 & 0.7 & 3.2 \\
\hline TETRAETHYL SILANE & $\mathrm{Si}(\mathrm{C} 2 \mathrm{H} 5) 4$ & 144.32990 & $606.000 .31-0.70$ & $<25 \%$ & 0.50 & 0.1089 & 0.4 & 1.4 \\
\hline n-PENTASILANE & $\begin{array}{l}\mathrm{SiH} 3 \mathrm{SiH} 2 \mathrm{SiH} 2 \\
\mathrm{SiH} 2 \mathrm{SiH} 3\end{array}$ & 152.523 & $628.600 .32-0.80$ & $<10 \%$ & 0.5 & 0.1429 & 0.7 & 3.2 \\
\hline $\begin{array}{c}(3,3,3- \\
\text { TRIFLUOROPROPYL)METHYLDICHLORO } \\
\text { SILANE }\end{array}$ & $\begin{array}{c}\mathrm{C}(\mathrm{F} 3) \mathrm{CH} 2 \mathrm{CH} 2 \mathrm{Si} \\
(\mathrm{Cl} 2) \mathrm{CH} 3\end{array}$ & 211.085 & $561.700 .36-0.80$ & $<10 \%$ & 0.5 & 0.09634 & 0.7 & 3.1 \\
\hline
\end{tabular}

Table 5. Other silanes

\begin{tabular}{|c|c|c|c|c|c|c|c|}
\hline COMPOUND & Structure & $\begin{array}{c}\mathrm{M} \\
{[\mathrm{kg} / \mathrm{kmol}]}\end{array}$ & $T_{c}[K] \quad \Delta T r$ & $\begin{array}{c}\lambda \text { (DIPPR } \\
\text { claimed error) }\end{array}$ & a $\lambda(0.618)$ & $\Delta \mathbf{m} \% \Delta$ & $\Delta \mathrm{M} \%$ \\
\hline TRIMETHYL SILANOL & $(\mathrm{CH} 3) 3 \mathrm{SiOH}$ & 90.1964 & $562.500 .54-0.71$ & $<10 \%$ & 0.500 .1147 & 0.3 & 0.8 \\
\hline $\begin{array}{l}\text { DIMETHYLDIMETOXY } \\
\text { SILANE }\end{array}$ & $(\mathrm{CH} 3) 2 \mathrm{Si}(\mathrm{OCH} 3) 2$ & 120.2224 & $524.000 .37-0.68$ & $<25 \%$ & 0.500 .1067 & 0.2 & 0.7 \\
\hline $\begin{array}{l}\text { TRIMETHOXY } \\
\text { SILANE }\end{array}$ & $(\mathrm{CH} 3 \mathrm{O}) 3 \mathrm{SiH}$ & 122.1952 & $525.000 .30-0.80$ & $<10 \%$ & 0.500 .1331 & 0.8 & 3.5 \\
\hline $\begin{array}{l}\text { VINYLTRIMETHOXY } \\
\text { SILANE }\end{array}$ & $\mathrm{CH} 2 \mathrm{CHSi}(\mathrm{OCH} 3) 3$ & 148.2320 & $553.700 .32-0.80$ & $<10 \%$ & 0.500 .1360 & 0.8 & 3.3 \\
\hline METHYL SILICATE & $\mathrm{Si}(\mathrm{OCH} 3) 4$ & 152.2210 & $562.800 .49-0.70$ & $<3 \%$ & 0.500 .1451 & 0.8 & 2.0 \\
\hline $\begin{array}{l}\text { HEXAMETHYL } \\
\text { DISILAZANE }\end{array}$ & $\begin{array}{l}(\mathrm{CH} 3) 3 \mathrm{SiNHSi} \\
(\mathrm{CH} 3) 3\end{array}$ & 161.3928 & $544.000 .54-0.73$ & $<10 \%$ & 0.500 .0860 & 1.0 & 2.6 \\
\hline $\begin{array}{l}\text { 3-(TRIMETHOXYSILYL)-1- } \\
\text { PROPANETHIOL }\end{array}$ & $\begin{array}{c}(\mathrm{OCH} 3) 3 \mathrm{SiCH} 2 \\
\mathrm{CH} 2 \mathrm{CH} 2 \mathrm{SH}\end{array}$ & 196.3400 & $657.600 .30-0.74$ & $<10 \%$ & 0.500 .1468 & 0.3 & 1.1 \\
\hline $\begin{array}{l}\text { 3-CHLOROPROPYL } \\
\text { TRIMETHOXYSILANE }\end{array}$ & $\begin{array}{c}(\mathrm{CH} 3 \mathrm{O}) 3 \mathrm{Si}(\mathrm{CH} 2) 3 \\
\mathrm{Cl}\end{array}$ & 198.7200 & $647.300 .22-0.73$ & $<10 \%$ & $\begin{array}{lll}0.50 & 0.1408\end{array}$ & 0.7 & 2.1 \\
\hline $\begin{array}{l}\text { TETRAETHOXY } \\
\text { SILANE }\end{array}$ & $\mathrm{Si}(0 \mathrm{CH} 2 \mathrm{CH} 3) 4$ & 208.3280 & $592.200 .32-0.74$ & $<5 \%$ & 0.500 .1190 & 0.8 & 2.8 \\
\hline $\begin{array}{l}\text { 3-(TRIETHOXYSILYL) } \\
\text { PROPIONITRILE }\end{array}$ & $\begin{array}{l}\mathrm{NCCH} 2 \mathrm{CH} 2 \mathrm{Si} \\
(\mathrm{OCH} 2 \mathrm{CH} 3) 3\end{array}$ & 217.3380 & $672.100 .30-0.80$ & $<10 \%$ & 0.500 .1475 & 0.8 & 3.4 \\
\hline $\begin{array}{l}\text { METHYLTRIACETOXY } \\
\text { SILANE }\end{array}$ & $\begin{array}{c}\mathrm{CH} 3 \mathrm{Si}(\mathrm{OC}(=\mathrm{O}) \\
\mathrm{CH} 3) 3\end{array}$ & 220.2520 & $663.500 .47-0.80$ & $<10 \%$ & 0.500 .1406 & 0.9 & 3.2 \\
\hline $\begin{array}{c}\text { gamma-AMINOPROPYL } \\
\text { TRIETHOXY } \\
\text { SILANE }\end{array}$ & $\begin{array}{c}\mathrm{Si}(\mathrm{OCH} 2 \mathrm{CH} 3) 3 \\
\mathrm{CH} 2 \mathrm{CH} 2 \mathrm{CH} 2 \mathrm{NH} 2\end{array}$ & 221.3690 & $634.600 .22-0.78$ & $<25 \%$ & 0.500 .1526 & 1.7 & 5.5 \\
\hline $\begin{array}{c}\text { ETHYLTRIACETOXY } \\
\text { SILANE } \\
\end{array}$ & $\begin{array}{c}\mathrm{CH} 3 \mathrm{CH} 2 \mathrm{Si} \\
(\mathrm{OC}(=\mathrm{O}) \mathrm{CH} 3) 3\end{array}$ & 234.2790 & $672.100 .42-0.80$ & $<10 \%$ & $\begin{array}{lll}0.50 & 0.1379\end{array}$ & 0.8 & 3.2 \\
\hline
\end{tabular}




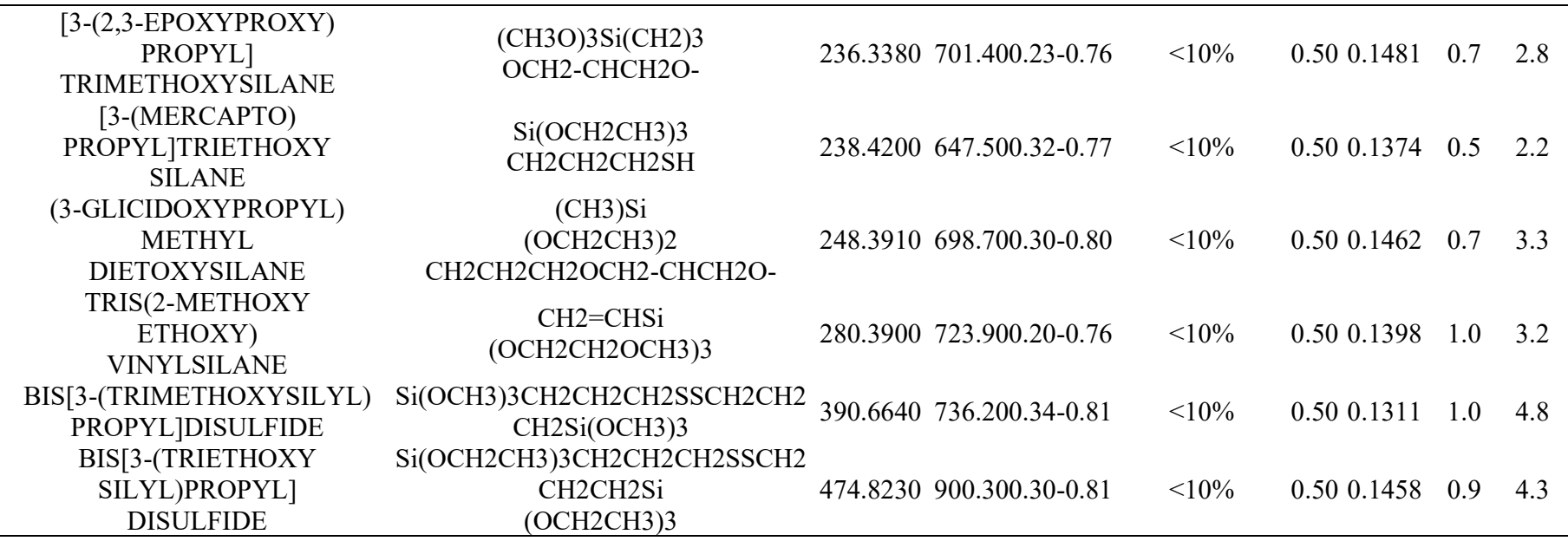

\section{RESULTS AND DISCUSSION}

In the discussion about the results, it is very important to outline the need of a large and accurate database containing reliable data with a clear claimed accuracy in large temperature ranges for a number of compounds as large as possible.

The DIPPR database contains in a common reduced temperature range (usually from 0.3 to 0.8 ) for each compound whether experimental thermal conductivity data with their sources or $\lambda$ data obtained from a linear regression obtained by the available experimental data and some other predicted data (when this is possible).

Finally, without a reliable rigorous theory of the liquid phase, it has to be again pointed out that an acceptable matching has to be reached between accuracy and generality of the equations minimizing the number of parameters characterizing the single compound.

Substantially, given the very different and complicate structures of the investigated silanes and siloxanes, the obtained results are generally satisfying as follows:

- on the basis of the data collected from the DIADEM database, the use of the Eq. (5), already given for different organic families, is generalized, taking into account the value of the thermal conductivity at a specific value of the reduced temperature as shown by the expression (6) to cover silanes and siloxanes;

- the families differ from each other for the value of the exponent a (the same for the compounds of each family, with the only exception of silane characterized by small value of the molar mass $\mathrm{M}$ );

- factor A has a clear physical meaning expressed by Eq. (6);

- the five investigated families are characterized by very different and complex structures;

- the method can be easily extended to other families.

- the method proposed in the present paper generally leads to low average absolute deviations, being less than 5\%.

\section{REFERENCES}

[1] Latini, G., Di Nicola, G., Pierantozzi, M. (2016). A method to estimate the thermal conductivity of organic alcohols in the liquid phase at atmospheric pressure or along the saturation line. Fluid Phase Equilibria, 427: 488-497. https://doi.org/10.1016/j.fluid.2016.08.010

[2] Latini, G., Di Nicola, G., Pierantozzi, M. (2017). Liquid thermal conductivity prediction for alkanes, ketones and silanes. Physics and Chemistry of Liquids, 55(6): 747765. https://doi.org/10.1080/00319104.2016.1277720

[3] DIADEM Professional-The DIPPR Information and Data Evaluation Manager for the Design Institute for Physical Properties-Full public version release 22/904/2020.

[4] Baron Fourier, J.B.J. (1822). Théorie analytique de la chaleur. Chez Firmin Didot, père et fils.

[5] Assael, M.J., Trusler, J.M., Tsolakis, T.F. (1996). An introduction to their prediction: thermophysical properties of fluids. World Scientific. https://doi.org/10.1142/p007.

[6] Govender, O., Rarey, J., Moller, B.C., Ramjugernath, D. (2011). A New Group Contribution Method for The Estimation of Thermal Conductivity for Non-Electrolyte Organic Compounds. University of KwaZulu-Natal Durban.

[7] Horvath, A. (1992). Chemical structure generation from the properties of pure organic compounds. Studies in Physical and Theoretical Chemistry, 75: 1-1489.

[8] Poling, B.E., Prausnitz, J.M., O'connell, J.P. (2001). Properties of Gases and Liquids. McGraw-Hill Education.

[9] Latini, G. (1977). Liquid thermal conductivity, correlations and estimations. Bull. Int. Inst. Refrig. 57: 1446-1473.

[10] Baroncini, C., Di Filippo, P. (1979). Thermal conductivity of liquids: comparison of predicted values with experimental results at different temperatures. High Temp. High Press. 11: 58.

[11] Baroncini, C., Di Filippo, P., Latini, G., Pacetti, M. (1981). Organic liquid thermal conductivity: A prediction method in the reduced temperature range 0.3 to 0.8 . International Journal of Thermophysics, 2(1): 2138. https://doi.org/10.1007\%2FBF00503572

\section{NOMENCLATURE}

$\left.\begin{array}{ll}\mathrm{M} & \begin{array}{l}\text { molecular weight } \\ \mathrm{kg} / \mathrm{kmole} \\ \mathrm{T}\end{array} \\ \mathrm{T} & \mathrm{K}\end{array}\right)$


$\Delta_{\mathrm{m}} \% \quad$ average absolute deviations

$\Delta_{\mathrm{M}} \%$ maximum absolute deviations $\lambda$ thermal conductivity

$\mathrm{W} /(\mathrm{m} \mathrm{K})$ 